\title{
Hamsa
}

Journal of Judaic and Islamic Studies

2| 2015

Varia

\section{Sabios y santos de Silves emigrados al Mágreb}

\section{Manuela Marín}

\section{(2) OpenEdition}

Journals

Edición electrónica

URL: https://journals.openedition.org/hamsa/813

DOI: 10.4000/hamsa.813

ISSN: 2183-2633

\section{Editor}

CIDEHUS - Centro Interdisciplinar de História Culturas e Sociedades da Universidade de Évora

\section{Referencia electrónica}

Manuela Marín, «Sabios y santos de Silves emigrados al Mágreb», Hamsa [En línea], 2 | 2015,

Publicado el 31 diciembre 2015, consultado el 13 mayo 2021. URL: http://journals.openedition.org/ hamsa/813 ; DOI: https://doi.org/10.4000/hamsa.813

\section{(c) $($ ) () $\Theta$}

Hamsa est mise à disposition selon les termes de la Licence Creative Commons Attribution - Pas d'Utilisation Commerciale - Pas de Modification 4.0 International. 


\title{
Sabios y santos de Silves emigrados al Mágreb
}

\author{
Manuela Marín \\ Madrid
}

\section{Resumo:}

Com o avanço da "Reconquista" cristã na Península Ibérica, muitos ulemas emigraram para outros países islâmicos. Neste artigo, analisam-se nove biografias de ulemas de Silves (atualmente Portugal) que emigraram para Marrocos e que viveram entre o séc. VI/XII e a primeira metade do VII/XIII. Através do estudo dos seus perfis individuais, emergem três padrões biográficos: primeiro, o "clássico" ulema islâmico, incorporado nas redes de transmissão do conhecimento; segundo, a figura do santo, e, terceiro, o do letrado que era também santo. É dedicada uma atenção especial ao último, através da biografia de Ibn Gālib, que se tornou o santo patrono da cidade marroquina de Alcácer Quibir.

Palavras-chave: ulemas, santos, emigração, Silves, Marrocos

\begin{abstract}
:
With the advance of the Christian "Reconquista" in the Iberian Peninsula, many scholars ('ulam $\bar{a}^{\prime}$ ) migrated to other Islamic countries. In this article, nine biographies of scholars from Silves (in nowadays Portugal) who migrated to Morocco and who lived during the $6^{\text {th }} / 12^{\text {th }}$ century and the first half of the $7^{\text {th }} / 13^{\text {th }}$ century are examined. Throughout the study of their individual profiles, three biographical patterns emerge: first, the "classical" islamic scholar, incorporated to the networks of the transmission of knowledge; secondly, the figure of the saint, and thirdly, the scholar who is also a saint. Special attention is dedicated to the last, through the biography of Ibn Ghalib, who became the saint patron of the Moroccan city of Alcazarquivir.
\end{abstract}

Key words: 'ulamā', saints, emigration, Silves, Morocco

\section{Resumen:}

Con el avance de la "reconquista" cristiana en la Península Ibérica, muchos ulemas emigraron a otros países islámicos. En este artículo, se analizan las biografías de nueve ulemas de Silves (en el actual Portugal) que emigraron a Marruecos durante el siglo VI/XII Y la primera mitad del VII/XIII. A través del estudio de sus perfiles individuales, se observan tres modelos: en primer lugar, el ulema "clásico", integrado en las redes de transmisión de la ciencia; en segundo lugar, la figura del santo y, finalmente, el ulema que también es un santo. Se dedica especial atención a este último, mediante la biografía de Ibn Gālib, que se convirtió en el santo patrón de la ciudad marroquí de Alcazarquivir.

Palabras clave: ulemas, santos, emigración, Silves, Marruecos 
La emigración de miembros de las élites urbanas desde al-Ándalus al norte de África en los siglos XII-XIII es un fenómeno bien conocido y documentado, especialmente a través de la literatura biográfica. Sus causas son evidentes: junto a la atracción que ejercían, para los sabios y literatos que integraban en parte esas élites, las cortes soberanas del Mágreb, por entonces sede del poder político que dominaba al-Ándalus, ha de tenerse en cuenta la presión ejercida por el avance de los reinos cristianos (Castilla, Portugal) hacia el sur peninsular ${ }^{1}$.

En esta ocasión voy a ocuparme del caso particular de los sabios y santos de Silves que emigraron a lo que hoy conocemos como Marruecos. Se trata de un ejemplo representativo, pues a pesar de que contiene un número no muy elevado de personajes, se incluyen entre ellos perfiles biográficos de cierta diversidad, que abarcan tanto recorridos típicos del ulema clásico como identidades en las que confluyen saberes eruditos y dedicación mística, o en las que esta última es la predominante. Todo ello refleja, sin duda, el panorama más general de la actividad intelectual y religiosa del al-Ándalus de su tiempo, incorporado al de un Mágreb que conocía, en ese tiempo, un pujante desarrollo de la vida religiosa y los fenómenos de santidad: una época que ha sido acertadamente denominada, por Halima Ferhat, como "los siglos de la fe" $\mathrm{fe}^{\prime 2}$. Son los siglos, desde luego, en los que la tradición escrita biográfica del Mágreb se asienta sobre el registro de las "vidas de santos", a diferencia de lo ocurrido en al-Ándalus, donde ese mismo registro había premiado y premiaba las biografías de los sabios. Aunque no se puede establecer una dicotomía estricta entre ambas tradiciones, puesto que a la andalusí concurrieron nombres tan notables como los de los norteafricanos qāọī 'Iyāọ o Ibn'Abd al-Malik al-Marrākušī, el hecho es que la memoria de la santidad, contrapuesta o al menos paralela a la del saber, conoció un florecimiento mucho más notable en el Mágreb que en al-Ándalus ${ }^{3}$. De todo ello serán testimonios notables las biografías de los sabios y santos de Silves que quiero presentar aquí.

Salvo error por mi parte, se conocen los nombres de nueve sabios de Silves que abandonaron su lugar de origen para instalarse en la otra orilla del Estrecho en esta época ${ }^{4}$. Voy a centrarme, en primer lugar, en aquéllos que tienen el perfil que acabo de definir como el de un "ulema clásico", es decir, poseedor de conocimientos en ciencias islámicas y miembro de una red de maestros y discípulos que las difunden. Esta clase de sabios está generalmente inserta en ámbitos urbanos de cierta entidad y se conecta entre sí, a menudo, por lazos de parentesco, construyendo un espacio genealógico de la transmisión del saber; al mismo tiempo, ocupan cargos destinados a la gestión de los asuntos privados y públicos de la comunidad: son jueces, jurisconsultos, muftíes, almuédanos, directores de la oración, $y$, a veces, miembros de la administración "civil", es decir, recaudadores de impuestos o incluso gobernadores.

Ejemplo casi perfecto de todo ello es el primero de los sabios en el que me voy a detener, Muḥammad b. 'Abd Allāh b. Aḥmad b. Mas'ūd b. Mufarriŷ b. Mas'ūd b. Șan'ūn b. Sufyān, conocido como Ibn al-Qanțarī, que murió en Marrakech el 4 de dūl-hiŷŷade 561 (1 de octubre de 1166). En otro lugar me he ocupado de la biografía de este personaje y de su familia, una de las más destacadas en la historia de Silves, por lo que no voy a repetir aquí lo

\footnotetext{
${ }^{1}$ M. Marín, “Des migrations forcées: les savants d'al-Andalus face à la conquête chrétienne”, M. Hammam, coord., La Méditerranée occidentale au Moyen Age, Rabat, 1995, pp. 43-59 y A. Rodríguez Figueroa, "Un ejemplo de exilio forzado: la conquista cristiana de Almería en 1147", Biografías almohades II (EOBA, X), Madrid-Granada, 2000, pp. 11-55.

${ }^{2} \mathrm{H}$. Ferhat, Le Maghreb aux XIlème et XIIlème siècles: les siècles de la foi, Casablanca, 1993.

${ }^{3}$ Sobre la literatura hagiográfica marroquí, H. Ferhat, Le soufisme et les zaouyas au Maghreb, Casablanca, 2003 y J. J. Sánchez Sandoval, Sufismo y poder en Marruecos, Cádiz, 2004, pp. 26-68.

${ }^{4}$ Hay además casos de ulemas de Silves que se asentaron en otros lugares de al-Ándalus, como el Levante o Almería.
} 
ya dicho con anterioridad ${ }^{5}$. Conviene sin embargo hacer notar que la muerte de Ibn alQanțarī en Marrakech es un síntoma, no de una voluntad expresa de emigración hacia Marruecos, sino de su presencia como miembro de una delegación de notables de Silves que habían acudido a la capital almohade para rendir obediencia al entonces califa, Abū Ya'qūb Yūsuf (r. 558-580/1163-1184). Ahora bien, por muy "casual" que pudiera haber sido su fallecimiento en Marrakech, lo que se documenta con él es la presencia regular de sabios andalusíes en la corte almohade, lugar de atracción indudable para quienes pertenecían a las aristocracias locales andalusíes.

No mucho después que Ibn al-Qanțarī, murió en Marrakech, en šawwāl de 569/mayo 1174, otro sabio de Silves, Muhammad b. 'Umar al-Šawwāšǐ al-Šilbī, en quien se puede reconocer una trayectoria más apoyada en una emigración voluntaria: experto en literatura, poesía y lengua árabe, parece que recaló en Marrakech tras haber hecho la peregrinación a La Meca y comprobar que sus oportunidades profesionales eran mucho mejores en el Mágreb que en al-Ándalus. Pero la conexión con su lugar de origen se deja ver, de modo muy notable, en la atribución que le hace su biógrafo de una obra sobre la rebelión de lbn Qasī, titulada Iarwat al-murīdīn bi-I-Andalus ${ }^{6}$. Carecemos de información sobre las motivaciones de la composición de esta obra, así como sobre su contenido y orientación; si la escribió durante el periodo de su vida que pasó en Marrakech, es posible que lo hiciera a instancias del poder almohade o para congraciarse con él. En todo caso, es notable que se haya conservado su memoria?.

Otros dos ulemas de Silves se instalaron en Marrakech en esta época, compartiendo, a diferencia del anterior, unas bien establecidas conexiones con el mundo del saber de su lugar de origen. Yahyà b. Hassān al-Murādī al-Naḥwī, que como su nisba indica, era especialista en gramática árabe, procedía de la fortaleza (hịșn) de Murŷĩ (Monchique). Nada se nos dice, en su biografía, de las razones que le impulsaron a establecerse en Marrakech, aunque no parecen difíciles de deducir: Silves había sido ocupada por los cristianos entre 585/1189-90 y 587/1191 y, como en el caso anterior, Yahyyà b. Ḥassān renunció a permanecer en su región de origen, donde había sido educado y había estudiado con maestros locales. En Marrakech ejerció como almocrí hasta su muerte en 614/1217-18 ${ }^{8}$.

Algunos de los maestros de Yahyà b. Ḥassān lo fueron también de Abū I-Baqā' Ya'īš b. 'Alī b. Ya'ǐš b. Mas'ūd al-Anșārī al-Šilbī, conocido como Ibn al-Qadīm (m. 626/1228-29). Especialista en lecturas coránicas y Tradición Profética, Ibn al-Qadīm abandonó Silves tras la conquista cristiana - en este caso su biógrafo deja clara constancia de ello - para instalarse primero en Marrakech y luego en Fez. Se conocen los títulos de algunas de las obras que compuso, por los cuales puede confirmarse su perfil de sabio "clásico": un tratado sobre las

\footnotetext{
5 "Familias de ulemas en Silves", B. Soravia y A. Sidarus, eds., Literatura e Cultura no Gharb alAndalus, Lisboa, 2005, pp. 201-219.

${ }^{6}$ Al-Suyūțī, Bugyat al-wu'āt fí țabaqāt al-lugawīyīn wa-l-nuḥāt, ed. 'A. M. 'Umar, El Cairo, 2005, no 347, tomándolo de Ibn al-Zubayr, Șilat al-Șila. Esta biografía se hallaba en las partes perdidas de la obra de Ibn al-Zubayr; v. Kitāb Șilat al-Șila, vol. 5, ed. 'A. al-Harrās y S. A'rāb, Al-Muḥammadīya, 1995, no 233 (apéndice).

${ }^{7}$ La obra de Ibn Șāhị al-șalāt de parecido título - Tawrat al-murīdīn- no se ha conservado, aunque fue utilizada por Ibn al-Abbār, que la cita en su Hulla (M. Meouak, "Al-Hulla al-siyarā, d'Ibn al-Abbār: sources écrites et données historiques", Ibn al-Abbar, politic i escriptor àrab valencià, Valencia, 1990, pp. 251-266) y por Ibn 'Abd al-Malik al-Marrākušī en su diccionario biográfico al-Daylwa-l-takmila. Sobre la obra de Ibn Șāḥib al-șalāt, v. la introducción de 'Abd al-Hādī al-Tāzī a su edición de al-Mann bi-l-imāma, Beirut, 1987. En ella cita al-Tāzī (p. 25, nota 2) la Tawrat al-murīdīn de Muhammad b. 'Umar al-Šawwāšī, pero se la atribuye a un tal Ismā'īl b. 'Umar al-Šawwāš. Cita para ello la biografía de al-Suyūțī mencionada en la nota anterior; consultada la Bugyat al-wu'āt, no encuentro allí la biografía de Ismā'īl b. 'Umar al-Šawwāš. Véase también M. Fierro, "El título de la crónica almohade de Ibn Șāḥib al-șalāt", Al-Qanțara, XXIV (2003), pp. 291-294.

${ }^{8}$ Ibn al-Zubayr, Șilat al-Ṣila, ed. É. Lévi-Provençal, Rabat, 1937, 380.
} 
virtudes de Mālik b. Anas, otro sobre lecturas coránicas y un tercero sobre exégesis de la Tradición Profética ${ }^{9}$.

Fez atrajo igualmente a otro sabio de Silves, Aḥmad b. Mūsà b. 'Abd Allāh b. Bakr b. Muzāḥim al-Lajmī ( $m$. después de 600/1203-4), que se había formado en lecturas coránicas en su lugar de origen, con los mismos maestros de los ulemas que se han mencionado ya; debido a ello se dedicó, una vez en Fez, a la enseñanza de la lengua árabe y del Corán ${ }^{10}$.

Finalmente, dos ulemas procedentes de la región de Silves escogieron su residencia en las regiones septentrionales de Marruecos y especialmente en Ceuta ${ }^{11}$. El primero de ellos, Muraŷyyà b. Yūnus b. Sulaymān b. 'Umar b. Yahyyà al-Gāfiqī al-Murŷīqi (m. ca. 600/1203-4), procedía, como indica su nisba, del hișn de Murŷīq y, tras haber estudiado en Silves, pasó gran parte de su vida oscilando entre ambas orillas del Estrecho; enseñó (era gramático) en Ceuta y en Tánger. Fue autor de un šarḥ de la Qașīda de al-Ḥușrī sobre la lectura coránica de Nāfi', que era la predominante en el Mágreb ${ }^{12}$.

Del segundo de estos dos sabios se tienen menos noticias, pero se sabe que procedía de al-'Ulyā (Loulé), aunque estaba considerado como perteneciente a la "gente" de Silves, es decir, que habría sido educado en esta ciudad. Muḥammad b. Mufaḍ̣al b. Muhīb al-Lajmī, que así se llamaba, se instaló en Almería cuando "el enemigo se apoderó del país de sus antepasados", pero murió en Ceuta en 645/1247-48 ${ }^{13}$.

Si se intentan extraer conclusiones de estas siete biografías de sabios de Silves emigrados a Marruecos, lo escaso de la muestra no impide reconocer algunas constantes. Además del evidente encaje en un movimiento de traslado hacia el Mágreb por parte de miembros de las élites andalusíes atraídas por el pujante poder almohade - lo que se observa en la preferencia por Marrakech -, se detectan igualmente tendencias hacia otros núcleos urbanos, destacando los situados en la zona más septentrional del territorio, Ceuta y Tánger. Como se verá, a ellos hay que añadir la ciudad de Alcazarquivir; Ceuta, por su parte, seguirá representando un papel importante, no sólo como "puerta" de Marruecos, sino también como un espacio con características propias que hacían atractiva a la ciudad para quienes abandonaban al-Ándalus en busca de patrocinio y mecenazgo ${ }^{14}$.

Estos sabios de Silves y su región procedían de un entorno intelectual compacto, en el que habían compartido un sistema de continuidad en la transmisión de las ciencias islámicas: varios de ellos eran discípulos de los mismos maestros. Pertenecían, por tanto, a una misma tradición de enseñanza, bien establecida para entonces en Silves, y que atraía a discípulos de las zonas circundantes a la ciudad, como atestigua el hecho de que algunos de estos sabios sean originarios de Murŷiq o de al-'Ulya ${ }^{-15}$. No es menos importante señalar que se trata de sabios especializados en su mayoría en las disciplinas de la lengua árabe y las lecturas coránicas, materias a su vez intrínsecamente relacionadas y que conocieron un gran

\footnotetext{
${ }^{9}$ Ibn al-Abbār, al-Takmila li-Kitāb al-Șila, ed. F. Codera, Madrid, 1887-89, 2110; Ibn al-Qāḍī, Ŷadwat aliqtibās, Rabat, 1973-74, II, 658.

${ }^{10}$ Ibn al-Abbār, al-Takmila li-Kitāb al-Șila, ed. I. al-Ḥusaynī, El Cairo, 1955, 245; Ibn 'Abd al-Mālik alMarrākušī, al-Dֵaylwa-l-takmila, I, ed. M. Ibn Šarīfa, Beirut, s.a., 845.

${ }^{11}$ Sobre la ciudad en general y sobre su capacidad de atracción para las élites andalusíes, v. H. Ferhat, Sabta, des origines au XIVeme siècle, Rabat, 1993 y M. al-Šarīf, Sabta al-islāmīya: dirāsāt fí l-ta'rīj aliqtișādī wa-l-iŷtimā' ī, Tetuán, 1996.

12 Ibn al-Zubayr, Șilat al-Ṣila (al-qism al-țāliț), ed. 'A. S. al-Harrās y S. A'rāb, al-Muḥammadīya, 1993, 81; Ibn al-Abbār, al-Takmila, ed. I. al-Ḥusaynī, 1838; al-Suyūțī, Bugyat al-wu'āt, II, 1988. 'Alī b. 'Abd alGanī al-Ḥusrī (m. 488/1095) fue almocrí en Ceuta y gozó de gran fama; v. I. al-Jațīb, Al-Haraka al'ilmìya fí Sabta jilāl al-qarn al-sābi', Tetuán, 1986, pp. 112 y 116.

${ }^{13}$ Ibn al-Jațīb, al-Ināța fi ajbār Garnāța, ed. M. 'A. 'Inān, El Cairo, 1973-77, II, p. 418.

${ }^{14} \mathrm{H}$. Ferhat, Sabta, pp. 305-314.

${ }^{15}$ Otro rasgo significativo es la presencia entre estos ulemas de algunas nisbas sudarábigas, sobre lo cual v. M. Marín, "A l'extremité de I'Islam médiéval: élites urbaines et islamisation dans l'Algarve", Annales: Histoire. Sciences Sociales, 53 (1998), pp. 361-381.
} 
desarrollo en al-Ándalus a partir del siglo $\mathrm{V} / \mathrm{XI}$ y muy especialmente en los siglos $\mathrm{VI} / \mathrm{XII}$ y $\mathrm{VII} / \mathrm{XIII}{ }^{16}$.

Una última conclusión llevaría a pensar que, como en otros casos similares de emigración al Mágreb desde al-Ándalus, estos sabios de Silves no tuvieron problema alguno en integrarse en una sociedad islámica vecina a la suya propia y con cuyas capas más ilustradas compartían un mismo "capital simbólico" e intelectual, que se extendía por todo el mundo islámico de su tiempo (y de otros anteriores y posteriores). Lo mismo puede observarse en otras trayectorias contemporáneas de andalusíes y magrebíes instalados en el Medio Oriente islámico ${ }^{17}$. Pero no puede dejarse de lado que estas continuidades se sitúan en contextos históricos que difieren unos de otros y están condicionados por evoluciones políticas, económicas y sociales, en las que se insertan, irremediablemente, las tendencias intelectuales de cada época.

Así, dentro de los esquemas biográficos que se acaban de presentar, se observa una predilección por ciertos campos de estudio - lengua árabe, gramática, lecturas coránicas que coinciden con la evolución general de la vida intelectual andalusí en época almohade, cuando el derecho (fiqh) retrocedió ante otras disciplinas como éstas y las relativas a la Tradición Profética ${ }^{18}$.

Otro aspecto históricamente identificable en la evolución del Occidente islámico del periodo que va desde la última parte del dominio almorávide al de los almohades tiene que ver, y mucho, con el llamativo desarrollo de movimientos sufíes, que tienen raíces precedentes, pero que alcanzan en esos momentos una repercusión social y política muy notable. Incluso en estos perfiles de sabios "clásicos" que acabamos de observar, y a los que se supone, por tanto, alejados en principio de esta clase de dedicación religiosa, se deslizan datos que permiten comprobar hasta qué punto su actividad intelectual no estaba al margen de los cambios e innovaciones que les rodeaban. Así, hemos visto cómo uno de estos sabios de Silves, Muhammad b. 'Umar al-Šawwāšī, fue autor de una obra sobre la rebelión dirigida en el Algarve por Ibn Qasī (m. 546/1151), en principio en contra de los almorávides y luego de los almohades, a los que terminó por unirse. Este movimiento, de carácter originalmente religioso y hasta escatológico, no puede desgajarse de un entorno más general en el que se estaban dando corrientes de renovación y contestación respecto a poderes políticos que parecían incapaces de garantizar la seguridad de las comunidades musulmanas de alÁndalus frente a la amenaza cristiana ${ }^{19}$.

Es este un contexto en el que el paso de las "ciencias islámicas", tal como están representadas por los siete sabios de Silves emigrados al Mágreb - y por muchos otros de sus contemporáneos - hacia una práctica religiosa que se vive de forma exclusiva y que llega a adquirir perfiles inequívocamente calificables de ejemplares, se convierte en una opción voluntariamente asumida. Es más: el registro escrito de las vías de la santidad empieza a dar lugar, sobre todo en el Mágreb, a caracterizaciones biográficas que prescinden de toda

\footnotetext{
${ }^{16} \mathrm{~J}$. Zanón, "La actividad intelectual: las ramas del saber. Centros y métodos de conocimiento", in M. J. Viguera Molíns, coord. y prólogo, El retroceso territorial de al-Andalus. Almorávides y Almohades. Siglos XI al XIII. Historia de España Menéndez Pidal, t. VIII-II, Madrid, 1997, pp. 551-584.

${ }^{17}$ Sobre lo cual, por ejemplo, L. Pouzet, “Un type d'échange interméditerranéen au MoyenÂge: les lectures du Coran entre l'Andalousie et Machreq", Actas del XII Congreso de la U.E.A.I. (Málaga, 1984), Madrid, 1986, pp. 657-678.

${ }^{18} \mathrm{M}$. Fierro, "Revolución y tradición: algunos aspectos del mundo del saber en al-Andalus durante las épocas almorávide y almohade", Biografías almohades, II (EOBA, X), Madrid-Granada, 2000, pp. 131165 y The Almohad Revolution. Politics and Religion in the Islamic West During the Twelfth-Thirteenth Century, Farnham (Surrey), 2012.

${ }^{19}$ La bibliografía sobre Ibn Qasī es ya considerable; v. la que menciono en mi artículo citado en nota 15. Añádase T. Nagel, "Le mahdisme d'Ibn Tūmart et d'Ibn Qasī: une analyse phénomenologique", Revue du Monde Musulmane et de la Méditerranée, 91-94 (2000), pp. 124-135 y R. El Hour, "Ibn Qasī, Abū I-Qāsim”, J. Lirola Delgado, ed., Biblioteca de al-Andalus, IV, Almería, 2006, pp. 365-371.
} 
relación con el mundo del saber organizado en torno a la transmisión de los textos para centrarse en la descripción acumulativa de los carismas. Se conserva, en las hagiografías marroquíes, el esquema de relación entre maestro y discípulo, perpetuando la imagen de la literatura biográfica clásica: pero lo que se entrega entre uno y otro no es ya, o no del todo, el conocimiento basado en un saber escrito y codificado, sino en el mucho más indefinible contacto con lo sobrenatural.

Las biografías de los sabios de Silves emigrados al Mágreb son ilustrativas de este proceso. Por una parte, hay quienes pertenecen a un mundo de relaciones intelectuales establecidas desde antiguo y que se gobiernan por un sistema general de relaciones de transmisión textual, que permiten a cualquiera de sus miembros integrarse en otros lugares donde se hayan establecido sistemas similares.

Por otro lado, a esas siete biografías, tan bien integradas en ese mundo que se autoevaluaba y concedía credenciales de autoridad traducidas en la inclusión de los sabios en los repertorios biográficos, hay que añadir otros perfiles menos ajustados a los requerimientos académicos de su tiempo, o que introducen en ellos elementos ajenos a lo que podía esperarse de un currículo estándar. Las dos biografías que voy ahora a presentar son claro ejemplo de este proceso, en el que hay que situar dos perfiles biográficos bien diferenciados: uno, el del "santo"; otro, el del "sabio-santo". Con ellos se completa el panorama antes iniciado y que hasta ahora únicamente se refería al perfil del "sabio".

La vida y milagros de Abū 'Abd Allāh Muḥammad b. Sālim al-Šilbī aparecen únicamente documentados en la literatura hagiográfica magrebi ${ }^{20}$, a diferencia de los textos referidos al resto de los personajes de Silves aquí citados y de los que hay constancia en la literatura biográfica dedicada a los ulemas. En las dos obras más antiguas que se ocupan de este personaje, las compuestas por los hagiógrafos magrebíes al-Tamīmī (m.604/1207-8)) y alTādilī (m. 628/1230-1) se dan algunos, aunque parcos, datos sobre su trayectoria individual: procedente de Silves, habría abandonado al-Ándalus tras la muerte de Ibn Qasī (lo que hace suponer que era uno de sus seguidores o murīdūn), para instalarse primero en Salé y luego en Fez, donde murió en fecha no precisada.

Nada se dice, en estas dos biografías, de la inclusión de Muhammad b. Sālim en el sistema tradicional de transmisión de las ciencias islámicas. Tampoco de sus conocimientos en ninguna de ellas. Por el contrario, su figura se define únicamente por su piedad religiosa: era, se afirma, hombre retirado del mundo y que practicaba largos ayunos de cuarenta días, dado a la vida errante tan característica de ciertas formas del sufismo y capaz, finalmente, de atraer a discípulos dispuestos a seguir su modelo de comportamiento ${ }^{21}$.

Para ilustrar su carácter de santidad, es decir, su capacidad para cambiar los elementos de la naturaleza mediante actos carismáticos o para mostrar con su ejemplo el modo de comportamiento ideal del creyente, conservaron sus biógrafos varios relatos.

Sólo uno de ellos aparece a la vez en las dos obras mencionadas, y no es quizá casual que sea aquel en el que se puede realmente identificar un elemento transformador de la naturaleza $y$, por tanto, constituir un acto auténticamente milagroso. He aquí su transcripción:

\footnotetext{
${ }^{20}$ Al-Tamīmī, al-Mustafād fí manāqib al-'ubbād, ed. M. al-Šarīf, Tetuán, 2002, II, no 30, p. 93 e lbn alZayyāt al-Tādilī, al-Tašawwuf ilà riŷāl al-tașawwuf, ed. A. al-Tawfiq, Rabat, 1984, no 130. Hay textos biográficos más tardíos, citados por los editores de al-Tamīmī y al-Tādilī, que reproducen las informaciones suministradas por estos autores.

${ }^{21}$ De la creciente e importante bibliografía reciente sobre la santidad en el Islam clásico y especialmente en el Mágreb señalo, como ejemplos, V. J. Cornell, Realm of the Saint. Power and Authority in Moroccan Sufism, Austin, 1998; D. Aigle, ed., Miracle et karāma, Turnhout, 2000; N. Amri y D. Gril, D., eds., Saint et sainteté dans le christianisme et l'islam, Paris, 2007; N. Amri, Les saints en Islam, les messagers de l'espérance: sainteté et eschatologie au Maghreb aux XIVe et XVe siècles, Paris, 2008 y R. Vimercati Sanseverino, Fès et sainteté, Rabat, 2014, además de las obras de H. Ferhat ya señaladas.
} 
Salió de viaje con un grupo [de sus discípulos] y sufrieron mucho por la sed, sin encontrar agua. El jeque Abū' Abd Allāh les dijo: ¿'me ocultaréis? Contestaron: sí. Entonces entró en el mar hasta que el agua le llegó al pecho; después se puso a cavar [allí] con las manos y les dio de beber un agua dulce, hasta que todos quedaron saciados ${ }^{22}$.

Confluyen en este breve texto varios de los temas recurrentes en los relatos hagiográficos de su época: la estrecha relación entre el ejercicio de la piedad religiosa y el abandono de la vida sedentaria, traducido en una peregrinación constante por lugares de condición adversa; el sometimiento a pruebas físicas como la sed o el hambre; el requerimiento de quien, sabedor de su capacidad carismática, sólo la utiliza con la condición de que no se haga pública, porque la santidad y su capacidad taumatúrgica no debe trascender de su círculo más íntimo.

El resto de las anécdotas o pequeños relatos relativos a Muḥammad b. Sālim se sitúan en Salé y en Fez, las dos ciudades marroquíes donde residió algún tiempo. Todos estos relatos aparecen únicamente en la obra de al-Tādili ${ }^{23}$, quien los recoge de discípulos del santo, testigos presenciales o incluso participantes en los hechos.

Es éste el caso de un suceso que tiene lugar en Fez y cuyo protagonista informó a al-Tādilī de lo siguiente:

Estaba yo en Fez y me fui al zoco con un dirham, para comprar carne con un qīrāțy gastar el otro qirāt [en otra cosa], cuando oí a alguien pedir [limosna] y me dije a mí mismo: le doy un qīrăt y me gasto el otro para mis cosas. Después se me ocurrió otra idea y era que el que pedía podía encontrar a otro que no fuera yo y que le diera algo, así que me quedé con mi dirham. En esto un hombre que estaba a mi lado me cogió de la ropa por detrás y me dijo: ¿por qué te has arrepentido de tu primer pensamiento? Me volví y era Abü' Abd Allāh b. Sālim.

En esta anécdota milagrosa, junto al elogio de la limosna como virtud característica de la piedad musulmana, por escaso que sea su importe, el perfil de santidad de Muhammad b. Sālim se afirma en su capacidad para leer el pensamiento ajeno, una característica repetidamente mencionada en muchas de las biografías de santos recogidas por la literatura magrebí.

De otro carácter son los dos restantes relatos, en los que, en realidad, no hay hechos de carácter milagroso, sino la recuperación de actitudes y reflexiones del santo, muy reveladoras de su concepción sobre las relaciones entre los seres humanos y la naturaleza, como forma de expresar y dar significado a la búsqueda y la integración de lo sobrenatural en la vida cotidiana.

El primero de estos dos relatos se abre con una advertencia de su narrador, Abū l-'Abbās Aḥmad b. Ibrāhīm al-Azdī, quien afirma que Muhammad b. Sālim solía expresarse por medio de parábolas $(a m \underline{t} \bar{l} l)$, de manera que quien no le prestaba la necesaria atención no captaba el auténtico significado de sus palabras. Da un ejemplo de ello: estando con él en una rábita en la que había un granado, Muhammad b. Sālim exclamó al contemplar el árbol: "quien no mira a este granado y mira a la tierra, no sabe cuándo echa hojas, ni cuando florece, ni cuando da fruto, ni cuando se cosecha; pero quien alza la vista hacia él, ve cuando cambia de un estado a otro hasta que se recogen sus frutos". Y estas palabras, añade Abū I-'Abbās, tenían un sentido que iba mucho más del obvio y aparente, puesto que se trataba de una alusión esotérica (ǐ̌āra) a la aleya coránica que dice "se apegó a la tierra y siguió su pasión" ${ }^{24}$. Así, continúa Abū l-'Abbās, el mensaje del santo se dirigía a quienes esto hacen, real y metafóricamente, de manera que se les ocultan las maravillas de la creación, mientras

\footnotetext{
${ }^{22}$ Hay pequeñas variantes textuales entre los textos de al-Tamīmī y al-Tādilī citados en nota 20; aquí sigo el relato del primero.

${ }^{23}$ Ibn al-Zayyāt al-Tādilī, al-Tašawwuf, no 130.

${ }^{24}$ Corán, VII, 176.
} 
que a quienes ponen su "intención" y su mirada en el territorio superior habitado por los ángeles, se les abren las puertas de lo sobrenatural y la contemplación no sólo de las maravillas terrestres, sino también de las celestes.

En el segundo relato, la relación con la naturaleza como fuente de santidad es más acusada aún que en esta "parábola del granado". Su narrador es también un testigo presencial, en este caso alguien que era entonces muy joven o casi un niño, Abū 'Abd Allāh Muḥammad b. 'Alī b. 'Abd al-Raḥmān al-Hawwārī. Cuenta Muḥammad b. 'Alī que en cierta ocasión se encontraba él, junto con su padre y 'Abd al-Raḥmān b. Yūsuf b. 'Ašra en una rábita de Salé conocida como Dār Umm al-Qāọi $i^{25}$. El niño que era entonces Muhammad b. 'Alī tendió la mano para arrancar unas hierbas silvestres, pero el santo se lo impidió, diciéndole a su padre: “¿por qué va a cogerlas por diversión, sin que le sean necesarias? ¡Cuántos animales podrían comerlas! ¡Cuántos animales podrían refugiarse a su sombra!” A continuación, todos los presentes compartieron una colación, cuyas sobras envolvió Muḥammad b. Sālim en un pañuelo, que llevó hasta su casa. Termina así el relato: "Cuando llegó a su casa y lo abrió, encontró que había allí unas cuantas hormigas. Entonces dijo: he sacado a estas hormigas de sus lugares de residencia. Y las llevó hasta devolverlas a donde habían estado".

Nada hay de milagroso en esta anécdota, si por milagroso se entiende, como se ha dicho, una alteración de los procesos de la naturaleza. En cambio, se observa una actitud ejemplar, y por tanto, debidamente recordada y registrada por escrito, en la que el entorno físico de la santidad adquiere relevancia, tanto mayor cuanto más humilde es: hierbas silvestres, insectos y hormigas se convierten aquí en muestras de la creación divina que deben preservarse con el máximo respeto, como manifestación de las maravillas de la creación. La intensa preocupación del santo por preservar la vida y el entorno de estas mínimas criaturas de Dios tiene, naturalmente, ecos en otras tradiciones religiosas, y en el cristianismo se encarnan significativamente en la figura de San Francisco de Asís (m. 1226), cuyo paralelo con otras manifestaciones similares de la santidad musulmana ha sido señalado por Halima Ferhat ${ }^{26}$. Al subrayar esta coincidencia, no se pretenden establecer contactos o influencias entre islam y cristianismo en este periodo, lo que cae fuera del propósito de estas páginas, pero sí indicar la existencia de fórmulas comunes de religiosidad en una época (siglos XII-XIII) en la que las fronteras entre los dos espacios mediterráneos eran mucho más porosas de lo que puede pensarse en la actualidad.

He mencionado, al comienzo de esta recreación del itinerario vital y religioso de Muhammad b. Sālim, que probablemente se trataba de uno de los seguidores del movimiento de Ibn Qasī, puesto que sus biógrafos hacen constar que abandonó al-Ándalus tras su muerte en 546/1151 (única referencia cronológica de que disponemos para ubicar en el tiempo a Muhammad b. Sālim). Quienes han estudiado la carrera de Ibn Qasī han subrayado el carácter esotérico y escatológico de su doctrina, que atrajo, según algunos, a amplias capas de las poblaciones rurales del occidente de al-Ándalus ${ }^{27}$. Lo que sí es evidente

${ }^{25}$ El editor de al-Tašawwuf identifica en nota, apoyándose en un artículo de M. Bencherifa, a la familia de los Banū 'Ašra, cadíes de Salé; la rábita en cuestión habría sido construida por una mujer de esa familia.

${ }^{26}$ En la introducción a su edición del texto hagiográfico de al-Tāhir al-Ṣadafī, al-Sirr al-Mașūn, Beirut, 1998, p. 24.

${ }^{27}$ P. Guichard, Les musulmans de Valence et la reconquête (XIe-XIIle siècles), Damas, 1990, I, p. 105ss., no duda en afirmar que "en varias zonas rurales de al-Andalus se habían desarrollado movimientos de carácter a la vez ascético y místico, quizá un poco comparables al marabutismo magrebí, pero con un soporte ideológico más elaborado, en el que es tentador ver a la vez una reacción contra el malikismo ambiente y una tendencia que podía desarrollarse más fácilmente en el medio rural, menos controlado fuertemente por la élite de los alfaquíes urbanos, medio rural al cual este movimiento suministraba quizá un arma contra la dominación administrativa, social y cultural de la ciudad". Esta dicotomía medio rural/medio urbano, tan cara a ciertas visiones de la historia andalusí, debe ponerse 
es que la figura de Muhammad b. Sālim pertenece a un ambiente muy específico, a una época en la que los procesos de renovación religiosa estaban siendo recreados y reconstruidos, tanto en los medios urbanos como en los rurales, con consecuencias que podían ser, a la vez, políticas, sociales e individuales. La inserción de Muhammad b. Sālim en un movimiento como el de Ibn Qasī, de características que, no por ser peculiares, dejaron de compartir un amplio espectro común con otras tendencias de renovación religiosa de su tiempo, explica hasta qué punto ese movimiento fue capaz de aglutinar trayectorias diversas, lo que explicaría parte de su éxito y, en este caso concreto, su capacidad de traslación a otros ámbitos geográficos, como fue el del Mágreb.

Puesto que Ibn Qasī fue capaz de extrapolar su experiencia personal de renovación religiosa a un movimiento político y armado en rebelión abierta contra el poder de su tiempo - los almorávides en su fase final -, se ha caracterizado a sus seguidores como "sufíes extremistas", es decir, opositores radicales a las construcciones estatales de su época, en las que contaban tanto los poderes dinásticos como las élites urbanas compuestas por las familias de notables que a su estatus económico unían la presencia, entre sus miembros, de ulemas y alfaquíes.

Es ésta una visión que se solapa con la ya aludida acerca de la dicotomía entre mundo rural y urbano en la Edad Media andalusí. En parte, aunque no del todo, esta dicotomía (mundo rural abierto a tendencias contestatarias/mundo urbano centro de élites controladoras de la ortodoxia) hunde sus orígenes en interpretaciones coloniales del ámbito magrebí, cristalizadas en categorías binarias tan conocidas (y actualmente tan discutidas) como las que enfrentaban en Marruecos, según la historiografía francesa, al bilād al-majzan con el bilād al-sība, el primero sometido a la autoridad del sultán y el segundo situado claramente fuera de ella.

Ninguno de estos enfrentamientos dicotómicos es suficientemente explicativo de una realidad que, por otro lado, se nos escapa en buena parte debido a la escasez de pruebas documentales. El santo de Silves emigrado a Salé y Fez, Muḥammad b. Sālim, pudo haber formado parte de los seguidores (murīdūn) de Ibn Qasī, y por tanto haberse considerado como elemento configurador de una "rebelión" contra formas esclerotizadas de la práctica religiosa islámica, pero el posible enfrentamiento entre campo y ciudad, sin que deba descartarse, no puede constituirse en elemento básico de interpretación de lo que fue, sin duda, un periodo de cambio en el que intervinieron muchos otros factores. Muhammad $b$. Sālim, o mejor dicho, su recuerdo biográfico tal como aparece recogido en las fuentes hagiográficas magrebíes, representa una entre otras muchas trayectorias contemporáneas de búsqueda de la santidad, con las que comparte carismas y entre las que destaca por su cercanía a la relación entre el mundo natural y el sobrenatural. Su itinerario individual se inserta en todos estos esquemas bien establecidos por la historiografía, pero aporta a ellos características propias e intransferibles, que son las que hacen de él una figura comprensible e incluso cercana a quienes, hoy en día, nos acercamos a su perfil biográfico.

Centrado éste, como se acaba de ver, en una dedicación absoluta a la religiosidad más acendrada, resulta en contrapartida sumamente interesante contrastarlo con el del último "emigrado" de Silves al que quiero referirme a continuación y con el que comparte una misma reputación de santidad.

Se trata de Abū I-Ḥasan 'Alī b. Jalaf b. Gālib b. Mas'ūd al-Anșārī al-Qurašī, apodado al-'Arîf por alguno de sus biógrafos, que se refieren a él como Abūl-Ḥasan Ibn Gālib, y conocido en la actualidad como Sīdī Bū Gālib, santo patrón de la ciudad marroquí de Al-Qașr al-kabīr (Alcazarquivir/Alcaçarquivir en las fuentes hispanas y portuguesas), donde murió el 4 de ŷumadà II de 568/21 de enero de 1173; había nacido a mediados de 484/1091.

en contraste con los datos de las fuentes árabes acerca de lbn Qasī y los apoyos que encontró entre los notables urbanos del Algarve; v. Marín, M., art. cit. en nota 15. 
No son pocas las fuentes que se ocupan de Ibn Gālib - al que me referiré así en adelante , y pertenecen tanto al género biográfico andalusí y norteafricano ${ }^{28}$, como a la tradición hagiográfica magrebí. El testimonio historiográfico sobre Ibn Gālib ya lo sitúa, de entrada, a caballo entre dos tradiciones escriturarias que no siempre coinciden, puesto que sus intereses tampoco lo hacen. En otras palabras, Ibn Gālib fue reconocido como sujeto digno de interés tanto por quienes recogían las vidas de los sabios como por los que registraban tradiciones, predominantemente orales, acerca de los santos. Por ésta y otras razones, cabe identificar a Ibn Gālib como un ejemplo de la intersección entre ciencia (islámica) y experiencia religiosa, y como eslabón en una cadena de transmisiones cognoscitivas y de modelos de ejemplaridad personal.

Daré primero los datos más relevantes de la biografía de Ibn Gālib ${ }^{29}$. Nacido y criado en Silves, en el seno de una familia acomodada, estudió en su ciudad natal, especializándose en división de herencias (farā'iḍ) y aritmética (hisāb), dos materias estrechamente relacionadas entre sí y que ofrecían la posibilidad de dedicarse a una actividad profesional remunerada. En Córdoba prosiguió Ibn Gālib su formación, que incluía conocimientos amplios de Tradición Profética (hadīt ), derecho (fiqh) y lecturas coránicas. Ibn 'Abd al-Malik al-Marrākušī es, de todos sus biógrafos, quien da más información sobre los maestros de Ibn Gālib, entre los que destaca los nombres de Abū I-Ḥusayn 'Abd al-Malik b. al-Ṭallā', Abū I-Ḥakam b. Barraŷān, Abū I-Qāsim b. Baškuwāl y Abū I-Walīd b. Mufarriŷ; con todos ellos, afirma, estableció Ibn Gālib una fuerte relación de discipulazgo (ṣahiba-hum), que también mantuvo, continúa diciendo, con Abū l-'Abbās Ibn al-'Arīf.

En esta serie de nombres, junto a ulemas de tipo "clásico", aparecen dos de los sufíes más conocidos de su tiempo, Ibn Barraȳān (m. 536/1141) e Ibn al-'Arīf (m. $536 / 1141)^{31}$. No es de extrañar, por tanto, que se indique en alguna de las biografías de Ibn Gālib su dedicación a las doctrinas místicas (tașawwuf). Pero ésta debió de ser una etapa relativamente tardía en la trayectoria vital de Ibn Gālib, quien, como se acaba de ver, había orientado en un principio su formación hacia materias eminentemente prácticas, como la relativa a la partición de herencias. No sorprende por tanto comprobar que, en su juventud, trabajó como secretario $(k \bar{a} t i b)$ para un miembro de la élite almorávide, al-Ḥâŷŷ b. Bulkās alLamtūnī, con el que alcanzó gran privanza e influencia ${ }^{32}$.

\footnotetext{
${ }^{28}$ Sobre las diferencias entre los diccionarios biográficos andalusíes y magrebíes, M. L. Ávila, "El género biográfico en al-Andalus", Biografías y género biográfico en el Occidente islámico (EOBA, VIII), Madrid, 1997, pp. 35-51.

${ }^{29}$ Me baso en Ibn al-Zayyāt al-Tādilī, al-Tašawwuf, no 81; Ibn al-Abbār, al-Takmila li-Kitāb al-Ṣila, ed. F. Codera, Madrid, 1887-89, no 1870; Ibn'Abd al-Malik al-Marrākušī, al-Daylwa-l-takmila, V, ed. I. 'Abbās, Beirut, 1965, no 415 (p. 208-212); Ibn al-Zubayr, Al-Qism al-ajīr min Kitāb Șilat al-Șila, ed. E. Lévi-Provençal, París, 1937, no 201; Ibn al-Qāḍī, Ŷaḍwat al-iqtibās, II, no 512; Ibn Qunfud̄, Uns al-faqīr wa-'izz al-ḥaqīr, ed. M. al-Fāsī y A. Faure, Rabat, 1965, p. 14 y Muḥammad b. Ŷa'far al-Kattānī (m. 1345/1926-27), Salwat al-anfāswa-muhāōatat al-akyāsbi-manuqbira min al-'ulamā'wa-l-șulahā,biFās, ed. 'A. A. al-Kāmil al-Kattānī, Ḥ. b. Muḥammad al-Ṭayyib al-Kattānī y M. b. Ḥamza b. 'Ali alKattānī, Casablanca, 2004, II, no 426 (p. 28-30). Un resumen de los principales datos biográficos de Ibn Gālib en J. Lirola Delgado, "Ibn Gālib al-Anșārī, Abū I-Ḥasan", J. Lirola Delgado y J. M. Puerta Vílchez, dirs., Biblioteca de al-Andalus, III, Almería, 2004, pp. 197-99 y el amplio estudio de 'A. S. al-Qaysī, "Min a'lām madīnat al-Qașr al-kabīr jilāl al-qarn 6 H/12 M: al-šayj al-zāhid Sīdī Abū l-Ḥasan 'Alī b. Jalaf al-Qurašī al-Šilbi", M. al-Magrāwī, ed., Madinat al-Qașr al-kabīr. Al-Dֵākirawa-l-ḥāḍir, Salé, 2000, pp. 75-102.

${ }^{30}$ P. de la Torre, "Ibn Barraŷān, Abū I-Hakam”, J. Lirola Delgado y J. M. Puerta Vílchez, dirs., Biblioteca de al-Andalus, II, Almería, 2009, pp. 578-81.

${ }^{31}$ J. Lirola Delgado, "Ibn al-'Arīf, Abū l-'Abbās”, ibid., pp. 469-76.

${ }^{32}$ No he conseguido identificar a este personaje en las fuentes árabes consultadas. Este dato lo da Ibn 'Abd al-Malik al-Marrākušī; por su parte, Ibn al-Zubayr añade que se trataba del señor de Segura, llamándolo al-Lamtūnī al-Ḥāŷy.
} 
A pesar de ello, y probablemente por el efecto de su contacto con los maestros sufíes mencionados, llegó un momento en que Ibn Gālib decidió "abandonar el mundo" y dedicarse a una vida de piedad y ascetismo; entre otras cosas, renunció a la cuantiosa herencia que había recibido de su padre y que llegaba a la suma de 12.000 dinares. Se trata de un itinerario relativamente común en los registros de la santidad en el islam; lo que llama la atención es que coincida con la de otros personajes cercanos a Ibn Gālib por diversas razones: así, entre quienes tuvieron relación con Ibn al-'Arîf, se cuentan los casos del sevillano Abū I-Walīd Ibn al-Mundir, seguidor de Ibn Qasī, y de Ibn al-Hạâŷy al-Lūrqī (m. ca. 550/1155). El primero fue cadí y el segundo secretario en época almorávide, antes de renunciar ambos a sus respectivos cargos para dedicarse a la vida religiosa ${ }^{33}$. El propio Ibn Qasī fue almojarife para los almorávides antes de sufrir su crisis espiritual ${ }^{34}$. Finalmente, no está de más señalar que Ibn al-'Arïf formó también parte de la administración almorávide, como encargado del gobierno del zoco en Valencia, donde residió algún tiempo.

Coinciden los biógrafos de Ibn Gālib en que fueron la enseñanza y el contacto con Ibn al'Arîf los que ejercieron sobre él una mayor influencia. De la estrecha relación que se desarrolló entre ambos da cuenta que en la recopilación de la correspondencia del sufí almeriense, titulada Miftāh al-sa'āda wa-taḥqīa țarīa al-sa'āda, 20 de sus cartas están dirigidas a Ibn Gālib, el mayor número de toda la colección dedicado, con diferencia, a un solo corresponsal.

Tomando, pues, a Ibn al-'Arīf como modelo, se dedicó Ibn Gālib, en los años siguientes a su renuncia a los bienes mundanos, a una vida errante (siyāha) en la que buscaba el contacto con otros ascetas y hombres de religión por todas las regiones de al-Ándalus. Se desconoce la fecha exacta en la que se trasladó al Mágreb, pero de nuevo es Ibn 'Abd alMalik al-Marrākušī el único de sus biógrafos que menciona que ello se debió a las pruebas sufridas durante el periodo de fitna en al-Ándalus, con lo que muy probablemente se refiera a la fragmentación del dominio almorávide en la Península ibérica y al surgimiento de poderes locales, lo que se suele conocer como "segundas taifas" o "taifas post-almorávides" y, más en concreto, a la rebelión de Ibn Qasi ${ }^{-35}$.

No cabe olvidar, por otra parte, la progresiva reducción del territorio andalusí que iba pasando a manos de los cristianos, en una erosión continua que demostraba la fragilidad de la comunidad islámica. De ello se hace eco una de las cartas enviadas por Ibn al-'Arīf a lbn Gālib, desgraciadamente sin precisiones cronológicas, pero en la cual el maestro alude al propósito de su discípulo de trasladarse a Silves, por mor de los "compañeros" sufíes que allí residían y con los cuales estaba en contacto. Ibn al-'Arīf se muestra decididamente contrario a esa idea, haciendo notar a Ibn Gālib que debía preocuparse, en primer lugar, de sí mismo y de su familia $(a h l)$; si, como se decía, el "enemigo" había aparecido en la región de Silves de forma amenazante, no debía moverse de donde estaba, confiando en todo caso en la protección divina y manteniendo, eso sí, el contacto epistolar con los sufíes de Silves ${ }^{36}$.

La mayoría de los biógrafos de Ibn Gālib mencionan únicamente su residencia en Alcazarquivir ${ }^{37}$, ciudad en la que falleció y donde está enterrado. Sin embargo, hay también informaciones sobre su paso por Fez: de ello queda constancia porque, según se dice, fue allí

\footnotetext{
${ }^{33}$ M. Fierro, "El sufismo", p. 488.

34 Ibid., p. 489.

35 ฯ. 'A. Dandaš, Al-Andalus fĩ nihāyat al-murābițīn wa-mustahill al-muwaḥhidīn. 'Așr al-țawā'if al-țānī 510-546/1116-1151, Beirut, 1988, y M. J. Viguera Molíns, “Historia política”, M. J. Viguera Molíns, coord. y prólogo, El retroceso territorial de al-Andalus, pp. 67-71.

${ }^{36}$ Ibn al-'Arīf, Miftāh al-sa'āda wa-taḥqīq tarīq al-sa'āda, ed. 'I. 'A. Dandaš, Beirut, 1993, p. 136.

${ }^{37}$ Como es sabido, la ciudad recibe también, en las fuentes árabes medievales, los nombres de Qașr 'Abd al-Karīm y de Qașr Kutāma. Véase G. Gozalbes Busto, “Alkazarquivir en la Edad Media. Contribución al estudio de la Historia de Marruecos", M. Olmedo Jiménez, dir., España y el norte de África. Bases históricas de una relación fundamental, Granada, 1987, I, pp. 281-289.
} 
donde enseñó los Sunan de al-Tirmidī a Abū Madyan ${ }^{38}$. Aunque cabría poner en duda la conexión de Ibn Gālib con Fez, por su tardía incorporación a los textos biográficos que a él se refieren, el caso es que el propio Abū Madyan, en un relato autobiográfico, afirma que estudió la obra de al-Tirmidīi con Ibn Gālib en aquella ciudad ${ }^{39}$. De este modo, Ibn Gālib se inserta en una cadena de conocimiento místico que conoció una enorme difusión en todo el norte de África.

No se ofrecen en los textos biográficos razones que expliquen por qué Ibn Gālib decidió instalarse de forma definitiva en Alcazarquivir, ciudad que entonces no podía compararse con las grandes capitales marroquíes, como Fez o Marrakech. Es de suponer que fue precisamente ese carácter de pequeño núcleo urbano y por tanto, alejado de las sedes más importantes del poder político, lo que atrajo sobre todo a Ibn Gālib, deseoso de seguir practicando la vida retirada a la que venía consagrándose en al-Ándalus. Tampoco hay que descartar que se hubieran instalado en la ciudad otros andalusíes vinculados como Ibn Gālib al entorno de Ibn al-'Arîf, lo que habría hecho de ella un lugar atractivo para ser elegido por él como residencia permanente.

En todo caso, en Alcazarquivir encontró Ibn Gālib el espacio más adecuado a su proyecto de vida religiosa y sapiencial, puesto que no abandonó la ciudad hasta su muerte y fue allí donde creó un núcleo de difusión de conocimientos místicos asegurado por la presencia de discípulos locales; destaca entre ellos Abū Muhammad 'Abd al-Ŷalīlb. Mūsà al-Qașrī (m. en Ceuta, 613/1216-17) ${ }^{40}$. Fue en Alcazarquivir donde Ibn Gālib se convirtió, al decir de lbn 'Abd al-Malik al-Marrākušī, en imán de los sufíes, que acudían a él y se beneficiaban de su contacto.

Recuerdan también los biógrafos de Ibn Gālib su autoría de varias obras, ninguna de las cuales se ha conservado ${ }^{41}$, pero cuyos títulos deben reseñarse: se trata en primer lugar de un texto titulado Kitāb al-yaqīn, de tema místico, que fue transmitido por 'Abd al-Ŷalīlb. Mūsà; parece haber sido su obra más alabada y difundida, aunque a ese título añade Ibn alZubayr los del Kitāb al-i'tibār y el Kitāb al-ayyām wa-l-ḥâyb, de cuyo contenido nada se sabe, aunque probablemente pertenecían a la misma temática.

Recogidos hasta aquí los datos biográficos que se han conservado a propósito de Ibn Gālib, es hora de completarlos con la descripción que algunos de sus biógrafos hacen de sus carismas, que ayudan a comprender la consideración que mereció por parte de las hagiografías magrebíes, que lo incorporaron a su propia tradición y lo insertaron en su reconstrucción del mundo de la santidad islámica de su tiempo.

Una de estas anécdotas se refiere a su renuncia a la herencia de su padre, ya mencionada anteriormente. Se trataba de un gesto ejemplar, puesto que todo ese dinero fue distribuido en limosnas, siguiendo una tradición reconocible en muchas otras vidas de santos musulmanes. Se estaría aquí ante un gesto iniciático para internarse en la vía del ascetismo

${ }^{38}$ Este dato no aparece en las biografías más antiguas de Ibn Gālib, pero sí en Ibn Qunfud̃ (m. 810/1407-8), Uns al-faqīr (quien añade que Abū Madyan también estudió fiqh con Ibn Gālib) y en Ibn al-Qāọī (m. 1025/1616), Ŷadwat al-iqtibās. Véase H. Ferhat, "Un maître de la mystique maghrébine au XIlème siècle: Abū Madyan de Tlemcen", Les siècles de la foi, pp. 55-78.

${ }^{39}$ Ibn al-Zayyāt al-Tādilī, al-Tašawwuf, p. 322.

${ }^{40}$ Sobre el cual, v. al-Tamīmī, Mustafād, no 67 e lbn al-Zayyāt al-Tādilī, al-Tašawwuf, no 241 (con más referencias a otras fuentes biográficas posteriores). En la segunda de estas obras se menciona también, como discípulo de Ibn Gālib, a Abū I-Ṣabr Ayyūb b. 'Abd Allāh al-Fihrī; según Ibn al-Zubayr, Abū I-Șabr mencionó a Ibn Gālib en su Barnāmaŷ, explicando que lo había ido a visitar varias veces a Alcazarquivir, lo que indica que, a diferencia de 'Abd al-Ŷalīl b. Mūsà, no se trataba de un discípulo local.

${ }^{41}$ A diferencia de lo que ocurre con su discípulo 'Abd al-Ŷalïl b. Mūsà, cuya obra Šu'ab al-īmān ha sido editada (Beirut, 1995 y El Cairo, 1996); también se conserva un ms. de su Šarh al-asmä' al-ḥusnà. Véase M. al-Magrawī, "Al-Šayj Abū Muhammad 'Abd al-Ŷalīl al-Qașrī: ḥayātu-huwa-ātā̄ru-hu", M. alMagrawī, ed., Madīnat al-Qașr al-kabīr, pp. 110-111. 
(zuhd), cuyo primer paso consiste en el desprendimiento de los bienes materiales. Lo que llama la atención en el desarrollo narrativo de esta anécdota es la intervención en ella del maestro de Ibn Gālib: en efecto, a Ibn al-'Arîf debió de parecerle que había algo de excesivo en ese gesto, y preguntó a Ibn Gālib si no consideraba que el reparto, en limosnas, del tercio de libre disposición según las normas jurídicas que regulan las herencias, había "purificado" el resto del legado ${ }^{42}$.

Una vez establecido en Alcazarquivir, la residencia de Ibn Gālib se convirtió en lugar de atracción para quienes, como él, buscaban su perfeccionamiento espiritual. Uno de sus discípulos contaba cómo en una ocasión, comprobó que había, en torno a su maestro, un grupo de santos personajes que eran todos capaces de caminar por los aires, añadiendo que en el rostro de uno de ellos se observaba una especie de quemadura que le habría producido esa clase de traslado milagroso ${ }^{43}$. Conviene recordar aquí la significativa presencia de este prodigio como seña de identidad de la santidad magrebí, muy relacionada con la peregrinación a La Meca ${ }^{44}$.

Es notable, con todo, que el único acto de carácter sobrenatural que se atribuye a Ibn Gālib no sea uno de los milagros que, como éste que se atribuye a sus visitantes, trascienda las leyes de la naturaleza, y que tan frecuentes son en las hagiografías magrebíes. Por el contrario, se subraya en él no tanto la capacidad taumatúrgica como la recepción sobrenatural del conocimiento, puesto que se afirma que el propio Ibn Gālib decía: "cuando no comprendo algo, miro a algún lado de mi habitación y lo encuentro escrito" ${ }^{45}$; es decir, hallaba la respuesta a una duda espiritual mediante el recurso a un mensaje trascendente que tomaba la forma de un texto escrito. No una voz carente de corporeidad, ni un mensajero angélico, ni una aparición o un sueño, vehículos habituales de esta clase de mensajes en las hagiografías, sino un texto que, por serlo, ratificaba en cierto modo su condición de ulema, por muy milagrosa que fuera su aparición.

Comparado el perfil de santidad de Ibn Gālib con el de otros santos magrebíes contemporáneos o posteriores, llama la atención que sus carismas tuvieran unas características tan poco extraordinarias; cabe preguntarse, por tanto, cómo tras su fallecimiento se llegó a decir que, con él, se había perdido uno de los cuatro "pilares" (awtād) que sostenían el ámbito de la religiosidad musulmana de su tiempo ${ }^{46}$. Bien es verdad que en el origen de esta expresión estaba su discípulo 'Abd al-Ŷalīl b. Mūsà (parte interesada en contribuir al reconocimiento de la santidad de su maestro) quien aseguraba haberla visto escrita en el cielo tras la muerte de Ibn Gālib, pero aun así no cabe duda de que su reputación en este sentido fue aceptada ampliamente y se fue perpetuando a través de los siglos hasta llegar a nuestros días.

La pérdida de las obras de tema místico de Ibn Gālib impide reconstruir su inserción en los movimientos sufíes de su tiempo; sin embargo, contamos con otros testimonios documentales que pueden ayudar a situarlo en ese contexto. Uno de ellos se encuentra en la biografía que le dedicó Ibn` Abd al-Malik al-Marrākušī, en la que puede leerse, entre otras

\footnotetext{
${ }^{42}$ El texto recogido por Ibn al-Zayyāt al-Tādilī dice literalmente: "Abū I-Ḥasan heredó de su padre cerca de 12.000 dinares. Renunció a ellos por ascetismo e Ibn al-'Arīf le dijo: Abū I-Ḥasan, ¿acaso no los ha purificado el tercio?" Ibn Qunfud, que reproduce este texto, añade una frase que quizá explique la reticencia de Ibn Gālib a aceptar la herencia paterna: "su padre no conocía bien el derecho" (kāna lā yuhssin al-fiqh), lo que podría implicar que había adquirido su fortuna de forma ilícita o al menos poco respetuosa con la normativa legal.

${ }^{43}$ A partir de Ibn al-Zayyāt al-Tādilī, esta información es reproducida por lbn 'Abd al-Malik alMarrākušĩ.

${ }^{44}$ M. Marín, "Le pèlerinage des saints", Melanges Halima Ferhat, Rabat, 2005, pp. 7-21.

${ }^{45}$ En Ibn Zayyāt al-Tādilī, Ibn 'Abd al-Malik al-Marrākušī e Ibn Qunfuḍ.

${ }^{46}$ Esta fórmula aparece en Ibn al-Zayyāt al-Tādilī, Ibn 'Abd al-Malik al-Marrākušī y al-Kattānī. Sobre el significado de awtād en la jerarquía mística, Ibn al-'Arabī, Terminología sufí, trad. A. Carmona, Murcia, 1990, p. 85 y Cornell, Realm of the Saint, p. 9.
} 
muchas cosas que se han ido señalando, lo siguiente, tomado de alguien que lo había conocido personalmente:

Era sabio, literato, poeta, hombre de religión, asceta, modesto. Cuando lo veías, te exhortaba simplemente con su estado espiritual (hāl), aunque estuviera callado, ya que en él predominaba la presencia [de la Verdad] (huụūr) y la conciencia de Dios Altísimo (murāqaba). Dios había reunido en él gran copia de ciencias, conocimientos y saberes (ādāb), especialmente la ciencia de lo esencial ('ilm al-ḥaqā'iq), las disciplinas ascéticas (riyāọīyāt), las ciencias de los tratos, los estados espirituales transitorios y las moradas ortodoxas (al-mu'āmalātwa-I-maqāmātwa-Iahwwāl al-sunnīya) y los comportamientos ortodoxos (al-ādāb al-sunnīya). Era tradicionista, y aseguró muchas transmisiones de hadīt. Encontró a muchos maestros, pero lo que predominaba en él era la conciencia de la conciencia de Dios y la preparación a Su encuentro, junto con la hermosa disposición a recibir la casa del otro mundo. Tenía 80 años y continuaba esforzándose como en su juventud. Fue el maestro de su tiempo en ciencia, estado espiritual y escrúpulo religioso ${ }^{47}$.

Por dos veces se subraya en este texto el carácter ortodoxo (sunní) de la práctica sufí de Ibn Gālib. Lo mismo hace otro biográfo posterior, Ibn al-Zubayr, que recoge las informaciones de Ibn 'Abd al-Malik al-Marrākušī y las somete a alguna crítica, pero que coincide con él en que Ibn Gālib "era, Dios tenga misericordia de él, de los sufíes sunníes, seguidores y rastreadores de las huellas de los piadosos antepasados (al-salaf al-șālih), cuya guía siguen; aferrado con fuerza al Libro y la sunna" ${ }^{\prime 8}$.

Todo ello no puede deslindarse de la relación de Ibn Gālib con su maestro Ibn al-'Arīf, de la que es elocuente muestra la correspondencia conservada en Miftāh al-sa'āda. El contenido de las cartas dirigidas por Ibn al-'Arīf a Ibn Gālib, además de documentar una estrecha relación afectiva entre ambos, permite adentrarse en la doctrina mística de Ibn al'Arîf y su firme apoyo en la revelación coránica, tanto como en su concepción del papel de los ulemas como sustentadores y transmisores del conocimiento ('ilm). En un periodo de expansión de movimientos sufíes en al-Ándalus y el Mágreb, la posición de Ibn al-'Arīf ha sido caracterizada como la de un desarrollo "moderado" de esas líneas de actuación religiosa, alejada de todo extremismo e incluso contemporizadora con los poderes políticos dominantes ${ }^{49}$.

Así se explica la falta de carismas extraordinarios en la biografía de Ibn Gālib, él mismo por otro lado un ulema de formación, y la alabanza que merece su estilo de sufismo ejemplar, que combina saberes clásicos del mundo de la ciencia islámica -poesía, literatura, lecturas coránicas, derecho, Tradición Profética - con una intensa vida espiritual en la que la presencia de la Verdad y la conciencia de Dios son constantes inalterables, a las que se ha llegado a través de una práctica singular de las disciplinas ascéticas.

Para terminar esta caracterización de Ibn Gālib, no está de más volver sobre los textos biográficos en los que se ha basado y, más especialmente, en los producidos sobre él en el Mágreb, que abarcan un periodo cronológico de gran extensión. En ellos se observa cómo, con el paso del tiempo, la figura de Ibn Gālib, bien definida en los más antiguos, como he tratado de mostrar, adelgaza sus rasgos más individuales para irse transformando en un eslabón de la cadena de transmisiones de santidad que se está convirtiendo en el eje de la religiosidad magrebí. En otras palabras: Ibn Gālib aparece cada vez más, en los textos más tardíos, como discípulo de Ibn al-'Arīf y, sobre todo, como maestro de Abū Madyan, que como un personaje autónomo y dotado de características propias. De esta forma se diluye su personalidad, y su engarce en el sufismo de su tiempo, que he intentado definir en lo que antecede, para convertirse en uno de los nombres singulares que dan sentido,

\footnotetext{
${ }^{47}$ Ibn 'Abd al-Malik al-Marrākušī, Dayl,V, no 415, p. 210-11.

${ }^{48}$ Ibn al-Zubayr, Al-Qism al-ajīr min Kitāb Șilat al-Șila, no 201, p. 100.

${ }^{49}$ M. Fierro, "El sufismo", pp. 487ss; V. Cornell, Realm of the Saint, pp. 19-23.
} 
genealógicamente, al ámbito de la santidad, ubicada en el tiempo y en el espacio a través de relaciones de santo a santo, en una geografía sagrada que todavía hoy se identifica en los santuarios que veneran sus tumbas y su memoria.

Por todo ello me ha parecido de interés trasladar la figura de Ibn Gālib hacia épocas más cercanas a la nuestra y examinar cómo se le presenta en textos españoles y franceses de la época colonial y en la historiografía, más reciente y local, sobre Alcazarquivir.

El estudio más completo publicado en la primera mitad del siglo XX sobre esta ciudad se debe a dos arabistas franceses, Edouard Michaux-Bellaire (1857-1930) y Georges Salmon $(1876-1906)^{50}$. Se trata de la monografía titulada "El-Qçar El-Kebir: une ville de province au Maroc septentrional" ${ }^{51}$, que presenta una recopilación exhaustiva y sistemática de la historia y la realidad contemporánea de Alcazarquivir, muy en la línea de las descripciones etnográficas de su época ${ }^{52}$.

No podía faltar en ella la enumeración y descripción de los lugares de culto musulmán, a las que añaden referencias biográficas sobre sus fundadores o sobre cualquier personaje relacionado con ellos.

El mausoleo de Ibn Gālib (que llaman marabout) cuenta, por tanto, con su biografía, en la que se destaca que fue maestro de su "compatriota" Abū Madyan. No se conocían entonces la mayor parte de los textos biográficos utilizados aquí y por ello los orientalistas franceses afirman que muy pocos autores árabes se habían ocupado de Ibn Gālib. De hecho, la única fuente que se cita sobre él es el Kitāb al-Istiqșā de al-Nāșirī (1835-1897), una obra histórica general sobre Marruecos ${ }^{53}$.

A pesar de la escasa información de que disponían, Michaux-Bellaire y Salmon consideran que Ibn Gālib era el personaje más eminente de todos los que habían sido enterrados en Alcazarquivir, por lo cual se convirtió rápidamente en el patrón de la ciudad, cuyos habitantes habían venerado como tal, hasta entonces, a Sīdī Bū Aḥmad (de quien sólo se conservaban tradiciones orales de carácter local). De la influencia intelectual de Ibn Gālib da idea que se puedan localizar en Alcazarquivir los enterramientos de muchos discípulos suyos; de su proyección social es testimonio una casida compuesta a mitad del s. XIX por un músico local muy popular, Sīdī Qaddūr al-'Alamī, en la cual se le alaba y se pide su intercesión ante Dios, reproducida y traducida por Michaux-Bellaire y Salmon ${ }^{54}$. Es también digno de señalar, a los ojos de estos autores, que alrededor de la tumba de Ibn Gälib se hallen los enterramientos de musulmanes de la región de buena posición económica: su precio podía alcanzar, a comienzos del siglo XX, los 400 duros.

La valoración que los dos autores franceses hacen de la figura de Ibn Gālib reposa sobre unos escasos testimonios textuales, de los cuales extraen, sin embargo, una conclusión muy similar a la de la historiografía marroquí tardía, subrayando su calidad de maestro de Abū Madyan como una de sus características más señaladas. Ahora bien, mientras que los hagiógrafos marroquíes ven en ello un símbolo de la pertenencia de Ibn Gālib a la cadena de santidad más prestigiosa del Mágreb (sin que pueda olvidarse su continuidad: Abū Madyan fue maestro de 'Abd al-Salām Ibn Mašišs, veneradísimo santo del norte de Marruecos, que lo fue a su vez de Abūl-Ḥasan al-Šãd dili $^{55}$ ), Michaux-Bellaire y Salmon parecen sorprendidos

\footnotetext{
${ }^{50}$ Dictionnaire des orientalistes de langue française, ed. F. Pouillon, Paris, 2008, pp. 680-82 y 860, respectivamente, con entradas debidas a Claude Lefébure y Julien Loiseau.

${ }^{51}$ Archives Marocaines, II/2 (1905), pp. 1-228.

52 Se tratan los siguientes temas: orígenes, historia, gobierno, administración, población, vestido, alimentación, matrimonio/bodas, nacimiento, circuncisión, entierros, régimen de la propiedad, comercio, fondaqs, industria, agricultura, pesca, miseria (con un apartado sobre la prostitución), instituciones comerciales, corporaciones, subastas, pesos y medidas, vida religiosa, supersticiones, grandes familias, familias de cherifes, vida religiosa, madrasas y mezquitas.

${ }^{53}$ Archives Marocaines, II/2 (1905), pp. 173-75.

${ }^{54}$ Ibid., pp. 194-95.

${ }^{55}$ M. Asín Palacios, "Šãdiilíes y alumbrados", Al-Andalus, X (1945), pp. 2-9.
} 
porque sea ése un timbre de gloria suficiente para merecer la veneración de toda una ciudad, y lo califican, en consecuencia, de "rare bonheur".

A partir de 1906 Michaux-Bellaire dirigiría la misión científica francesa en Marruecos, sustituyendo a su primer director, Salmon, fallecido ese mismo año. La orientación científica de la misión y del trabajo de Michaux-Bellaire consistía en "catalogar" toda suerte de conocimientos sobre ciudades, tribus y cofradías, para mejor organizar la penetración colonial y el dominio sobre el territorio y sus habitantes ${ }^{56}$; su última obra, en ese sentido, fue el volumen VII (1921) de Archives Marocaines, dedicado a Tánger y su región. La monografía sobre Alcazarquivir, publicada en 1905, iniciaba por tanto un largo camino de investigación, y cabe preguntarse por qué fue elegida para ello una pequeña ciudad del norte de Marruecos que no contaba con el prestigio histórico de otros núcleos urbanos de mayor importancia.

La biografía del propio Michaux-Bellaire puede dar la respuesta a esta pregunta. Cuando siendo joven se trasladó a Marruecos desde Francia, residió primero en Tánger y gracias a su dominio del árabe hablado, trabajó para la Legación francesa en la capital diplomática de Marruecos. Se instaló después en Alcazarquivir, donde, casado con una marroquí, vivió largo tiempo, sin perder por ello sus conexiones con la administración diplomática francesa (y más tarde, la del Protectorado) ${ }^{57}$. Todo esto explica, no sólo el interés por la ciudad donde está enterrado Ibn Gālib, sino la extensión y detalle de los conocimientos de Michaux-Bellaire sobre ella, y los apuntes sociológicos que introduce en su descripción del mausoleo del santo.

Algunas de las informaciones recogidas por Michaux-Bellaire y Salmon proceden, según nos informan, de letrados ( $f$ qīh) locales. Quizá fuera uno de ellos la fuente de un dato ofrecido por los dos autores franceses con alguna reserva: al referirse al mausoleo de Fāțima al-Andalusīya, recogen su posible relación familiar con Ibn Gālib, de quien habría sido hermana, aunque también hay quien afirma que era hermana de su padre ${ }^{58}$.

El estudio de Michaux-Bellaire y Salmon se convirtió en trabajo de referencia y modelo para otras descripciones posteriores. Hoy día se puede considerar como una obra maestra de su género, con las limitaciones y condicionamientos de lo que durante un tiempo se llamó "ciencia colonial", pero que gracias a su nada disimulada pretensión de exhaustividad, constituye un acervo documental de gran valor.

La autoridad de la obra de Michaux-Bellaire y Salmon se reconoce en un texto francés muy posterior, que carece de similares pretensiones científicas. Se trata del relato de viajes de Paul de Laget Au Maroc espagnol ${ }^{59}$, adornado con numerosas digresiones históricas, que dan un barniz cultivado a lo que no pasa de ser una descripción muy superficial de los lugares visitados. Entre ellos, Alcazarquivir, cuya abundancia de mezquitas y santuarios sorprende al viajero, quien pudo haber leído a Michaux-Bellaire y Salmon, ya que recoge lo esencial de sus datos al aludir a los dos "santos patrones" de la ciudad: "Moulay Ali Bou Râleb et Lalla Fâtma Al-Andaloûsya qui, tous deux naquirent à Silves au début du XIle siècle. Ali Bou Râleb, après avoir étudié à Cordoue, vint avec sa soeur au Maroc. II professa les traditions prophétiques en la fameuse Université de Karaouyîn à Fès, puis à El Ksaroùil forma de nombreux élèves" ${ }^{\prime 60}$.

Para Laget esta presencia espiritual es, por otro lado, una manifestación más de los lazos de Marruecos con una "Andalousie" que es un trasunto no sólo de al-Ándalus sino de la

\footnotetext{
${ }^{56}$ Lefébure, “Michaux-Bellaire”, p. 681.

57 Ibid.

${ }^{58}$ Archives Marocaines, II/2 (1905), p. 175.

${ }^{59}$ Publicado en Marsella, 1935. Laget es autor de otro libro de viajes, En Portugal (1932).

${ }^{60}$ P. de Laget, Au Maroc espagnol, pp. 238-39.
} 
Andalucía contemporánea, cuyos colores y perfumes cree reconocer en los paisajes que contempla ${ }^{61}$.

La continuidad de lo "andalusí/andaluz" en Marruecos, que aparece en esta obra de Laget ( $y$ en otros autores franceses), es uno de los tópicos más frecuentados por la literatura colonial española, como era inevitable, y se extiende por áreas temáticas que van desde la arquitectura o la música hasta las continuidades geográficas o la "hermandad" de raza y, sobre todo, la constatación de que lo mejor y más apreciable en la sociedad marroquí es aquello cuyos orígenes pueden vincularse a la huella andalusí, considerada siempre como de superior categoría a todo lo autóctono.

Este marco de referencias culturales se utiliza en un contexto de dominio colonial con significados ambivalentes, puesto que reclamar la superioridad de lo andalusí frente a lo puramente marroquí equivale a reivindicar un pasado en que la propia Península Ibérica pertenecía al mundo árabe-islámico. A menudo, esta contradicción se resolvía acudiendo a una caracterización de al-Ándalus como producto cultural fuertemente hispanizado y, por tanto, dotado de cualidades específicas que no podían encontrarse en otras áreas geográficas del islam medieval.

En lo que se refiere, más concretamente, al santo patrón de Alcazarquivir, nacido en Silves - no en lo que hoy es Andalucía, sino Portugal - estas líneas cruzadas de interpretación y utilización interesada produjeron, en la literatura colonial española sobre Marruecos, un par de ejemplos notables, que presento a continuación.

El primero de ellos data de los inicios del protectorado hispano-francés en Marruecos, establecido en noviembre de 1912. En la primavera del año siguiente, la Sociedad Española de Historia Natural patrocinó una expedición científica al territorio marroquí recién incorporado al dominio de España, en la que participaron zoólogos, geógrafos, geólogos y otros especialistas, y de la que se conservan un cierto número de testimonios escritos y publicados $^{62}$.

En mayo de 1913, los expedicionarios españoles llegaron a Alcazarquivir. Los tres científicos cuyos relatos de viaje se han preservado - Ángel Cabrera, Juan Dantín y Carmelo Bernaldo de Quirós - coinciden en su descripción de la ciudad, dotada, según ellos, de una estética arquitectónica y urbana que les recordaba, unánimemente, la de los pueblos toledanos. En esta recreación de las semejanzas entre España y Marruecos no se observa nada de la amable y sensorial memoria de la Andalucía islámica; si Alcazarquivir les recuerda Toledo es por las construcciones en adobe, las sucias callejas polvorientas, la disposición de puertas y ventanas, su aspecto, en suma, de "viejo poblachón toledano"63. Estamos, pues, lejos del exotismo multicolor de cierta literatura francesa (y española) sobre Marruecos y Andalucía.

Quizá llevados por esa conexión visual entre Alcazarquivir y los pueblos toledanos, los científicos españoles afirman que existen también razones históricas para entender las relaciones entre la ciudad y la región española, puesto que toledano era también, dicen el santo patrón de la ciudad "Sīdī Bū Galeb", cuyo mausoleo figura gráficamente en la obra de uno de ellos. Es más, esta presencia de un santo "español" se ve acompañada por la de otra santa del mismo origen, Fāțima al-Andalusìya, a la que convierten en sevillana.

Aunque uno de estos tres científicos cita la obra de Michaux-Bellaire y Salmon, no tuvo en cuenta que en ella se deja bien claro que el lugar de nacimiento de Ibn Gālib fue Silves.

\footnotetext{
${ }^{61}$ Cabe añadir, a esta visión un tanto convencional, su descripción del mausoleo de Lalla Fatima, que califica de "coqueto"; señala asimismo que en los barrios vecinos "s'aperçoivent de malheureuses filles de joie qui donnent surtout une impression de tristesse" (ibid., p. 239).

${ }^{62}$ M. Marín, “Un viaje científico: Cabrera, Dantín y Bernaldo de Quirós en Marruecos (1913)", H. de Felipe, L. López-Ocón y M. Marín, eds., Ángel Cabrera: ciencia y proyecto colonial en Marruecos, Madrid, 2004, pp. 137-171.

63 Ibid., p. 150.
} 
Todos coinciden en la "españolización" del santo patrón de Alcazarquivir y de Fāțima alAndalusīya, lo que les permite acentuar los lazos históricos entre la España de su época y el Marruecos que acaba de convertirse en su protectorado. En cierto modo, se trata de una maniobra de apropiación del pasado de la ciudad de Alcazarquivir, a través de un recurso que todavía hoy se puede observar en otros casos similares; sin ir más lejos, en la incorporación del "sevillano" Ibn Jaldūn a la historia intelectual de al-Ándalus. Pero si las raíces familiares de Ibn Jaldūn estaban realmente vinculadas a Sevilla, a Ibn Gālib se le hispaniza sin razón histórica alguna para ello. Se trata de una anécdota menor en el conjunto de los relatos de viaje producidos por la expedición de 1913, pero no hay que olvidar el carácter de científicos de sus autores, que pretenden en todo momento haber asegurado sus informaciones y proporcionar datos contrastables. En esta ocasión, sin embargo, parece que se dejaron llevar por una imaginación teñida de referencias coloniales ${ }^{64}$.

Medio siglo después se publicaba Alcazarquivir, 1950 (Tetuán, 1953) cuyo autor, Humberto Fernández-Cortacero, era interventor en la administración colonial española en Marruecos $^{65}$. La obra consiste en una serie de descripciones de la ciudad de Alcazarquivir a mediados del siglo XX, a las que se añaden recorridos históricos de cierta entidad. Pero donde Fernández-Cortacero se extiende más es en la biografía de Ibn Gālib, de quien ofrece un amplio retrato, recogiendo muchos de los datos que se han detallado antes. Su presentación del santo contiene algunos conceptos hoy día superados, pero lo que interesa destacar es que el establecimiento de Ibn Gālib en Alcazarquivir se presenta como acontecimiento fundador del florecimiento intelectual de la ciudad, ya que desde entonces "Alcázar se convierte en centro religioso y de estudios, a lo que contribuyó la instalación en la misma de musulmanes del oeste de la Península, famosos por su saber y cultura" ${ }^{\prime 66}$. En cuanto a la personalidad de Ibn Gālib, insiste Fernández-Cortacero en su carácter de místico y en su vinculación con la cadena de conocimiento sufí que le une a Abū Madyan y a 'Abd alSalām b. Mašišs, para concluir que su doctrina encaja plenamente en las características "españolas" de una corriente de mística musulmana caracterizada por Asín Palacios como de "misticismo y austeridad en lo emocional y panteísmo naturalista en lo especulativo"67.

La única autoridad a la que recurre Fernández-Cortacero en el largo texto que dedica a Ibn Gālib es precisamente la de Asín Palacios, aunque sin citar expresamente ninguna de sus obras. Es lástima que tampoco informe sobre la procedencia de la única información realmente novedosa que ofrece su trabajo: "su prestigio [de Ibn Gālib] ha calado en el alma marroquí, incluso entre los bereberes: en la tribu de Zerket de los Senhaya de Zereir, del Rif

\footnotetext{
${ }^{64}$ Cabe incluir, en ese mismo contexto ideológico, pero llevado a extremos exacerbados y en íntima relación con la rebelión del ejército africanista español en 1936, origen de la guerra civil, la obra del diplomático José Rojas y Moreno, conde de Casa-Rojas, Por tierras de Marruecos (aroma de recuerdos), publicada en Burgos, ca. 1936, en la que se recrea un viaje del jalifa Muhammad b. alMahdī por la zona del protectorado español y se menciona cómo, en Alcazarquivir, "la idea religiosa no puede estar ausente de un príncipe de los creyentes, y para permitirle orar, vamos todos hasta el santuario de Sidi Alí Bugaleb. Brota sangre de sacrificio de los cuellos segados de dos toros inmolados. Después se inicia el desfile en coche abierto con una cadencia pausada, solemne. El príncipe se ha puesto en contacto con su pueblo y éste le ha aclamado. Marruecos está con la verdadera España, y al sonar el himno que un “iArriba España!” corona, se alzan a millares los brazos en un sentir unánime y rotundo. Muere este primer día, que es nuncio de amanecer". Sobran los comentarios acerca de la retórica de "hermandad" hispano-marroquí que tan utilizada fue, con fines propagandísticos, por los voceros del régimen fascista nacido de la rebelión del 17 de julio de 1936 en Marruecos, aunque tiene raíces anteriores (J. L. Mateo Dieste, La "hermandad" hispano-marroquí. Política y religión bajo el Protectorado español en Marruecos, 1912-1956, Barcelona, 2003).

${ }^{65}$ Sobre esa figura y sus funciones, J. L. Villanova Valero, Los interventores: la piedra angular del Protectorado español en Marruecos, Barcelona, 2006.

${ }^{66}$ Alcazarquivir, 1950, p. 25.

${ }^{67}$ Ibid., p. 148.
} 
francés, existe la leyenda de poseer su tumba rodeada de las de once de sus descendientes" ${ }^{\prime 68}$.

En conclusión, lo que Fernández-Cortacero hace con Ibn Gālib es someterlo a un proceso similar al señalado anteriormente: hispanizarlo, esta vez en tanto que místico, como discípulo de un Ibn al-'Arîf que había sido igualmente integrado por Asín en una especificidad andalusí ${ }^{69}$.

También se refiere Fernández-Cortacero a Fāțima al-Andalusiya, esta vez para proponer que su supuesto parentesco con Ibn Gālib fuera tan sólo de carácter espiritual, aunque sugiere además un posible origen geográfico común.

El nombre de esta santa ha surgido en los diferentes textos coloniales en los que se recoge la localización de su santuario en Alcazarquivir y se mencionan, como hemos visto, notas contradictorias sobre su personalidad: hermana o tía de Ibn Gālib, discípula, según la leyenda, de Abū Madyan ${ }^{70}$, tan pronto se afirma que se desconoce su fecha de muerte como se da con precisión la de $642 / 1245^{71}$, se la hace toledana o se le confiere un origen sevillano...

Sólo existe una fuente árabe que se ocupe de esta santa mujer, y ninguno de los datos que se acaban de mencionar aparece en ella. En efecto, Ibn al-Zayyāt al-Tādilī incluye, en su repertorio hagiográfico, una "entrada biográfica" sobre "Fāțima al-Andalusīya"72 en la que se afirma que era una mujer piadosa (șāliḥa), "de la gente" de Alcazarquivir. A continuación relata un hecho milagroso en el que está involucrado un grupo de hombres que, al darse cuenta de lo sucedido, van a visitar a Fātima, a la que encuentran rezando; cuando termina sus oraciones, la santa les recomienda que no ignoren los carismas de la gente piadosa, demostrando de ese modo que era consciente de la cuestión que sus visitantes querían plantearle. Una segunda anécdota que cierra el texto biográfico sobre Fātima no tiene en realidad nada que ver con ella.

La parquedad de estos datos no debe sorprender en un contexto historiográfico que tiende a relegar $u$ ocultar las informaciones sobre las mujeres. En contraste, los autores occidentales ofrecen un retrato caleidoscópico que parece proceder en buena parte de su imaginación individual o colectiva, como en el caso de los científicos españoles de 1913, pero que también es posible que contenga rastros de tradiciones orales de carácter local, como las recogidas por Michaux-Bellaire durante su estancia en Alcazarquivir.

En todo caso, lo que llama la atención en todas estas referencias a Fātima al-Andalusīya es la permanencia de una presencia femenina junto a la figura de Ibn Gālib, con el cual se la relaciona. En Alcazarquivir, por otra parte, el mapa sagrado establecido por Michaux-Bellaire y Salmon da cuenta de una notable proliferación de santuarios y mausoleos situados bajo la advocación de mujeres ${ }^{73}$, entre las que destaca, junto a Fāțima al-Andalusīya, la madre del

\footnotetext{
68 Ibid.

${ }^{69}$ Las teorías de Asín sobre los orígenes de la mística de lbn al-'Arīf ( $v$. su edición, traducción y comentario de Mahāāin al-maŷālis de Ibnal-'Arīf, París, 1933) han quedado en buena parte superadas por la investigación posterior. Fernández-Cortacero se interesaba por el desarrollo del sufismo en Marruecos y se tiene noticia de dos artículos publicados por él sobre este tema: "Crónicas de Marruecos. El santuario de Muley Abdeselam", El Defensor de Granada, 11 de septiembre de 1927 y "La restauración del santuario de Sidi Kassem Zubair", Mauritania, no 240, noviembre 1947, 244-245 (debo estos datos a J. L. Villanova Valero, a quien se los agradezco vivamente). Fernández-Cortacero mantuvo comunicación epistolar con Asín, v. M. Marín, C. de la Puente, F. Rodríguez Mediano y J. I. Pérez Alcalde, Los epistolarios de Julián Ribera Tarragó y Miguel Asín Palacios. Introducción, catálogo e índices, Madrid, 2009, p. 701.

${ }^{70}$ Michaux-Bellaire y Salmon, “El-Qçar El-Kebir", p. 175.

${ }^{71}$ Fernández-Cortacero, Alcazarquivir, p. 148.

72 Ibn al-Zayyāt al-Tādilī, al-Tašawwuf, p. 331.

${ }^{73}$ Michaux-Bellaire y Salmon, "El-Qçar El-Kebir", p. 185-90, registran los nombres de Lālla Nabqà, Lālla al-'Alīya bint al-Rā'î, Lālla 'Ā'iša al-Quŷayrīya, Lālla 'Ā'iša al-Ṣadqīya (que según alguna tradición habría
} 
historiador Ibn 'Askar, Lālla 'A' iša, mujer de gran piedad cuya tumba (m. 969/1561-62) parece haber sido muy venerada ${ }^{74}$. Sería arriesgado inferir de ello, sin un estudio comparativo más amplio, una particular característica de la historia de la santidad en Alcazarquivir, pero es un aspecto que no puede dejarse de lado y que merecería ser investigado con más detalle ${ }^{75}$.

Tras esta breve digresión sobre Fātima al-Andalusīya y otras mujeres santas de Alcazarquivir, dedicaré, para terminar, alguna atención a la historiografía marroquí contemporánea y su valoración de la figura de Ibn Gālib, para lo cual no pretendo haber realizado sino unas calas significativas en la bibliografía a mi alcance. Las conclusiones a las que llego están, por tanto, sujetas a revisión.

Sin duda la obra de conjunto más importante sobre la santidad magrebí en los siglos VIVII/XII-XIII es la de Halima Ferhat, cuya autoridad en la materia la ha convertido en nombre de referencia al respecto. Entre otras cosas, Ferhat ha puesto en valor la identificación entre la figura del santo y el espacio urbano que acoge su tumba/santuario, y el patronazgo que ejerce desde ese ámbito arquitectónico y espiritual sobre el resto de la ciudad, proyectándose luego hacia las áreas circundantes y, a veces, hacia el conjunto del país. Pero entre los ejemplos que aduce para ello (Fez, Marrakech, Azemmour, Safi), todos bien conocidos, no se cuenta el de Alcazarquivir e Ibn Gälib, quizá porque, en la tradición historiográfica franco/marroquí a la que pertenece, Ibn Gālib no era considerado un santo carismático, sino más bien un sabio erudito ${ }^{76}$.

En la propia ciudad de Alcazarquivirse ha venido desarrollando, en tiempos recientes, una tradición historiográfica pujante, volcada hacia la recuperación de las "glorias" locales y reivindicativa de su papel como núcleo vertebrador de, por una parte, la resistencia a la presión invasora cristiana (con la batalla de Wādī I-Majāzin como hito histórico imprescindible, pero no único) y, por otra, la construcción de una tradición de enseñanza y difusión de las ciencias islámicas a lo largo de los siglos.

Estas características se dan en los tres textos examinados para este estudio ${ }^{77}$. El segundo de los temas que se acaban de citar es el que interesa aquí especialmente, y en él destaca la vinculación de las figuras de Ibn Gālib y su discípulo 'Abdal-Ŷalīl al-Qasrī con la narración configurativa de Alcazarquivir como ciudad islámica. Se recoge así la tradición historiográfica medieval según la cual la "historia" de una ciudad es la historia de sus sabios y santos. La excelsa calidad de estos personajes revierte sobre la ciudad que los acogió durante sus vidas o en cuyos cementerios reposan sus restos: esta simbiosis ciudad/santo patrón se reproduce

sido la esposa de Ibn Gālib) y Lālla 'Ā'iša 'aryānat al-ra's; y la tumba de Lālla 'Ā'iša al-Jaḍ̂ā' (p. 145) en la mezquita de ese nombre. Ha de señalarse igualmente la existencia de un masŷid al-banat y su adjunta madrasat al-banāt ("mezquita y escuela de las jóvenes"); v. 'A. S. al-Qaysī, Madīnat al-Qașr al-Kabīr. Ta'rijwa-muŷtama 'wa-wațā'iq, Al-Qașr al-kabīr, 2006, p. 24.

${ }^{74}$ Fernández-Cortacero, Alcazarquivir, p. 116, afirma que su culto había ya desaparecido en su época, aunque algunos ancianos recordaban el lugar de su enterramiento.

${ }^{75}$ A título de ejemplo, en la relación de 52 mezquitas y santuarios de Tetuán elaborada por Ahmad $\mathrm{R}^{\prime}$ honi a comienzos del siglo XX, sólo se menciona una mezquita con nombre de mujer (A. R'honi, Historia de Tetuán, Tetuán, 1953, pp. 76-81). En la actualidad, Rachid El-Hour y quien esto escribe preparan un estudio sobre las mujeres santas de Alcazarquivir basado en las tradiciones orales que todavía perviven sobre ellas en la ciudad.

${ }^{76}$ H. Ferhat, Les siècles de la foi, p. 55. A las apreciaciones de Michaux-Bellaire y Salmon citadas con anterioridad, añádase el comentario de Emile Dermenghem, que, en su biografía de Abū Madyan, cita, entre sus maestros, a "Alī ben Ghâlib (mort en 562/1166) qui fut surtout un érudit" (E. Demerghen, Vies des Saints musulmans, Plan de la Tour (Var), 1981 (reimpr. de la ed. de 1956), p. 354).

77 Muḥammad 'Abd al-Salām Bū Jalfa, Al-Ṭarīq li-ma'rifat madīnat al-Qașr al-kabīr, Tetuán, 1972; Muḥammad al-Magrāwī, ed., Madīnat al-Qașr al-kabīr. Al-D̄ākira wa-l-ḥāḍir y 'Abd al-Salām al-Qaysī al-Ḥasanī, Madīnat al-Qașr al-Kabīr. 
a lo largo de redes topográficas que cubren el territorio magrebí y conforman una auténtica geografía de lo sagrado, en la que el espacio del mausoleo del santo es el punto focal de todo el diseño religioso.

Las biografías de Ibn Gālib en los textos marroquíes contemporáneos contribuyen a realzar su importancia como santo patrón de Alcazarquivir, atribuyéndole un carácter fundador: a través de su enseñanza y su conducta ejemplar la ciudad se integra en la red de difusión del conocimiento islámico y atrae a sabios de otros lugares, adquiriendo así una relevancia histórica que se proyecta hasta el tiempo presente.

Destaca, en los textos consultados a este respecto, una clara voluntad de establecer el renombre de Ibn Gālib a partir de sus méritos como sabio y de su enseñanza de materias islámicas, como la exégesis coránica o la Tradición Profética; sin que se deje de lado su perfil carismático, éste se diluye un tanto en comparación con la perspectiva anterior, que por otra parte se apoya en la documentación biográfica conservada. Se diría que existe un intento por despojar a Ibn Gālib de su proyección más popular, que es la que sigue atrayendo a peregrinos hacia su tumba, para insistir en los aspectos más "ortodoxos" de su personalidad. Un texto muy revelador de esta tendencia es el que le dedica 'Abd al-Salām alQaysī, historiador de Alcazarquivir, al referirse a los carismas de Ibn Gālib.

Empieza el texto $^{78}$ con una larga cita del historiador marroquí Ibrāhīm al-Qādīirī en la que se define el concepto de carisma (karāma) y se establecen muy claramente cuáles son las condiciones para que se reconozca su validez, entre las que destaca el consenso de los ulemas y expertos y la adecuación a la ortodoxia de quienes gozan de ese don.

A continuación, y como ejemplo de las virtudes que adornaban a Ibn Gālib y que se manifestaban a través de acciones milagrosas, se reproducen las mencionadas por Ibn alZayyāt al-Tādilī y que se han descrito más arriba: su capacidad para encontrar, en las paredes de su habitación, la respuesta a las cuestiones que le preocupaban, y la presencia de santos "voladores" en sus sesiones de enseñanza.

Pero lo más significativo del texto de al-Qaysi viene a continuación:

Respecto a los milagros que circulan en boca de la gente y que se atribuyen al šayj Ibn Gālib, son muchos, en calidad y en cantidad. Pero no se apoyan en cadenas de transmisión correctas, por lo cual hemos evitado mencionarlos. A pesar de lo cual, es digno de mención, en este capitulo, el hecho de que tanto la población de la ciudad como los que la visitan, de toda clase de procedencia y situación, están firmemente convencidos de la capacidad carismática del šayj Ibn Gālib y de sus virtudes. Todos ellos se dirigen a su mausoleo y visitan su tumba de manera acorde a la sunna y la ley islámica (...).

La voluntaria abstención del autor, que suprime todas las tradiciones orales que circulan alrededor de la figura de Ibn Gālib, es notable porque así se explicita, pero es paralela a la del resto de los textos consultados, en los que también se recogen, únicamente, las tradiciones escritas. El resultado es, como se ha dicho, tanto el refuerzo de un mensaje de ortodoxia como la depuración del culto de los santos, siempre con un gran potencial conflictivo en el contexto magrebí. Puede, pues, concluirse que, de las diversas elaboraciones a las que se ha visto sometida la figura de Ibn Gālib por la historiografía, esta última hace de él un símbolo del sufismo más respetuoso con la ortodoxia y, por tanto, más susceptible de ser aceptado por quienes se consideran sus garantes. En ese sentido, los historiadores citados coinciden plenamente con los biógrafos medievales de Ibn Gālib.

\footnotetext{
${ }^{78}$ Al-Qaysī, "Min a 'lām madīnat al-Qașr al-kabīr”, pp. 89-90.

${ }^{79}$ De su obra Al-Magribwa-l-Andalus fì ahd al-murābițīn, Beirut, 1993.
} 